\title{
POTENTIALITY OF BETAINE SUPPLEMENTATION FOR AMELIORATING THE DELETERIOUS EFFECTS OF DRINKING SALINE WATER ON PERFORMANCE AND PHYSIOLOGICAL PARAMETERS OF GROWING LAMBS
}

\author{
A.M.A. Hussein ${ }^{1}$ and M.M. Abdelsattar ${ }^{2}$ \\ 1- Animal Production Department, Faculty of Agriculture, Assuit University, Assuit 71515, Egypt, 2- Animal \\ and Poultry Production Department, Faculty of Agriculture, South Valley University, Qena 83523, Egypt
}

Received: 18 /8/2019

Accepted: 3/10/2019

\section{SUMMARY}

The aim of the current study is to examine the potentiality of betaine supplementation for ameliorating the deleterious effects of saline water consumed by growing lambs on performance and physiology indices. A Twenty Ossimi lambs, 9 months of age and $31.5 \mathrm{~kg}$ average weight were used in five months experimental period. Lambs were offered Na CI in drinking water with levels 0 and $15 \mathrm{~g} / \mathrm{l}$. Also, they were offered betaine in concentrate mixture with levels 0 and $2500 \mathrm{mg} / \mathrm{kg}$ concentrate. The two factors completed the set of four groups of interaction; control (SOBO), saline water(S1B0), betaine (SOB1) and saline water with betaine(S1B1).Water consumption and feed intake were recorded daily. Body weight, rectal temperature and respiratory rate were recorded every two weeks. Blood samples were collected monthly and plasma were separated and kept at $-24 C^{\circ}$ until later blood biochemistry analysis. The results showed that, saline water increased $(P<0.01)$ water consumption. Also, saline water decreased $(P<0.01)$ dry matter consumption, body weight and daily gain. On the other hand, saline water significantly $(P<0.01)$ increased the plasma albumin concentration.In contrast, betaine significantly $(P<0.01)$ increased the dry matter consumption, body weight and daily gain.In addition, betaine increased $(P<0.01)$ morning rectal temperature and increased $(P<0.01)$ plasma albumin concentration. On the other hand, betaine decreased $(P<0.05)$ the plasma cholesterol and triglycerides. In conclusion, supplemental dietary betaine enhanced growth performance and biochemical assays of lambs drinking fresh or saline water and decreased the deleterious effect of drinking saline water by growing lambs.

Keywords: Betaine, saline water, growth, plasma, lambs

\section{INTRODUCTION}

Saline water can be used as an alternative source of fresh water for livestock animals. However, the poor water quality can influence the water and feed consumption, health, and the production state of ruminants (NRC, 2007). In addition, Kellems and Church (2002) found that salts cause poor performance, illness or even death. Furthermore, Curran and Robson (2007) summarized the symptoms of salt poisoning in ruminants, salts cause excessive thirst, abdominal pain, increased urination, nasal discharge, lack of appetite,vomiting,diarrhea, nervous signs (star gazing, tremors, blindness, circling, head pressing, wobbly in the legs, and knuckling at the fetlocks, lying down,convulsions, and death ).

Adding betaine supplementation as osmoregulator to livestock diets has increased over the past twenty years (Feng et al., 2006). Betaine was discovered in the juice of sugar beets (Beta vulgaris) in the nineteenth century (Craig, 2004). Moreover, betaine is known as a methylamine compound due to its three chemically reactive methyl groups connected to the nitrogen atom of a glycine molecule (Yancey et al., 1982). Biologically, Kidd et al. (1997) showed that betaine has two main functions, as a methyl donor and as an osmolyte. As osmolyte. Betaine is necessary for the nervous, immune, renal and cardiovascular systems during salinity stress. Moreover, Virtanen (1995) showed that betaine enhances the animals' growth and improves metabolism during its exposure to different physiological stresses such as high salinity or drought. Due to the few studies on the role of betaine in salinity stress conditions, the present study was conducted to examine the ability of betaine to overcome the deleterious effects of consuming saline water on lambs' performance and their physiological conditions.

\section{MATERIALS AND METHODS}

The present experiment was carried out in the sheep farm of Animal Production Department, Faculty of Agriculture, South Valley University, Qena, Egypt, from March to July, 2016.

\section{Animals, diets and housing:}

A total of twenty Egyptian Ossimi lambs at nine months of age weighing $31.5 \mathrm{~kg}$ were assigned to four treatments $(n=5$ each $)$ with $2 \times 2$ factorial arrangement of treatments in Randomized Complete Block Design (RCBD) the initial body weight used as the blocks. Lambs were provided with $\mathrm{NaCI}$ in drinking water at the levels of $0 \%$ and $1.5 \%$. Also, 
betaine (Danisco Animal Nutrition, Cairo, Egypt) was supplemented with levels 0 and $2500 \mathrm{mg} / \mathrm{kg}$ concentrate mixture. The treatment groups werethe control group (S0B0), saline water group (S1B0), betaine group (S0B1) and saline water with betaine group (S1B1). The experiment lasted for 135 days.

The basal diet was formulated to meet the recommended nutrient requirements of growing lambs (NRC, 2007). The daily rations consisted of
$20 \%$ wheat straw (Triticum aestivum) as roughage and $80 \%$ a commercial concentrate mixture (ElKawthar Factory, Egypt). Chemical analyses of the experimental rations were carried out according to AOAC (2012) as shown in (Table 1). All animals received fresh or saline water ad libitum all over the experimental period.

Table 1.The chemical analysis of concentrate mixture and wheat straw (on dry matter basis)

\begin{tabular}{lcccc}
\hline Sample & CP $\%$ & EE \% & CF \% & Ash \% \\
\hline Concentrate & 17 & 3.15 & 13 & 9.7 \\
Wheat straw & 3.26 & 1.42 & 36.01 & 13.89 \\
\hline
\end{tabular}

$\mathrm{CP}=$ crude protein, $\mathrm{EE}=$ ether extract, $\mathrm{CF}=$ crude fiber.

Animals were housed in opened shaded grouped pens. The animals were kept under the same managerial conditions. The pens space was $72 \mathrm{~m} 2$ $(12 \times 6)$, surrounded by a $1.5 \mathrm{~m}$ height concrete wall, and covered by a roof of metal sheet at $4 \mathrm{~m}$ height. Ambient temperature and relative humidity were recorded daily during the experimental period inside each pen at 8:00 am and 2:00 pm using a digital thermometer.

\section{Performance measurements:}

The daily water consumption of each pen was measured using graduated cylinders. In addition, feed intake was recorded daily. Also, lambs were weighed at the beginning of the experiment and then weighed over two weeks through the experimental period. The lambs were fasted for 12 hours before weighing using a digital scale. In addition, daily gain was obtained over a two-week period. Both body weight and daily gain were analyzed as repeated measures.

\section{Blood plasma constituents:}

Blood samples were collected monthly at 8:00 am after overnight fasting. The blood samples were drawn from the jugular vein using $10 \mathrm{ml}$ plastic disposable syringes. Thereafter, blood samples were transferred in a heparinized tube, centrifuged at 2500 rpm for 20 minutes, plasma was collected and stored at $-20{ }^{\circ} \mathrm{C}$ until subsequent analysis. After blood plasma recovery, metabolites were determined using a spectrophotometer. Plasma concentrations of total protein, albumin, cholesterol, triglycerides and glucose were measured using local commercial colorimetric assay kits (Spectrum Diagnostics, Egypt).Globulin was calculated as the difference between total protein and albumin.

\section{Rectal temperature and respiration rate:}

Rectal temperature and respiration rate were recorded at 8:00 am and 14:00 pm every two weeks. The rectal temperature was measured by a clinical digital thermometer (model HKH-6102) inserted into the animal rectum for 2 minutes to almost full length. While respiration rate was measured by counting the flank movements per minute using a stopwatch.

\section{Statistical analysis:}

The differences among factors levels (saline water and betaine) and their interactions were statistically analyzed in $2 \times 2$ factorial arrangement in RCBD design with the model: $\mathrm{Y}_{\mathrm{ijkl}}=\mu+\mathrm{S}_{\mathrm{i}}+\mathrm{B}_{\mathrm{j}}+(\mathrm{SB})_{\mathrm{ij}}+$ $\epsilon_{\mathrm{k}}+\epsilon_{\mathrm{ijk}}$. Where, Yijk is the observation, $\mu$ is the general mean, $\mathrm{Si}$ is the effect of ith level of saline water, $\mathrm{Bj}$ is the effect of $\mathrm{jth}$ level of betaine, (SB)ij is the interaction between ith level of saline water and $\mathrm{j}^{\text {th }}$ level of betaine, $\epsilon \mathrm{k}$ is the effect of $\mathrm{k}^{\text {th }}$ block, $\epsilon_{\mathrm{ijkl}}$ the error related to individual observation.

The data were analyzed using the GLM procedure of SAS (SAS Institute, 2013). Differences between means were tested using Duncan's multiple-range test (Duncan, 1955), $\mathrm{P}<0.05$ was set as the limit of significance. Differences between treatments (least square means of interactions) were tested using pairwise tests of values. The effect of treatments on blood parameters and animals' body weight were analyzed using the analysis of variance with time (month or week) as repeated measures.

\section{RESULTS}

\section{Water consumption:}

The results of water consumption are shown in Table (2). Saline water increased $(\mathrm{P}<0.01)$ the water consumption throughout the experimental period. However, betaine did not affect lambs' water consumption. The interaction showed that both S0B0 and S0B1 groups had significantly $(\mathrm{P}<0.01)$ lower water consumption than both $\mathrm{S} 1 \mathrm{~B} 0$ and $\mathrm{S} 1 \mathrm{~B} 1$ groups through the experimental period. In addition, the water consumption of S0B1 group was significantly $(\mathrm{P}<0.05)$ lower than the S0B0 group only in the fourth month. Moreover, the water consumption of S1B1 group was $8.35 \%(\mathrm{P}<0.01)$ and $13.90 \%$ $(\mathrm{P}<0.05)$ higher than the S1B0 group in the third month and fifth month, respectively. 
Egyptian J. Anim. Prod. (2019)

Table 2. Water consumption (l/day/head) of growing lambs as affected by saline water, betaine, and their interaction during the experimental period

\begin{tabular}{|c|c|c|c|c|c|}
\hline Factors & First Month & $\begin{array}{l}\text { Second } \\
\text { Month }\end{array}$ & Third Month & Fourth Month & Fifth Month \\
\hline P- value of salinity & $<.0001$ & $<.0001$ & $<.0001$ & $<.0001$ & $<.0001$ \\
\hline Fresh & $4.29^{b} \pm 0.10$ & $5.20^{\mathrm{b}} \pm 0.09$ & $6.70^{\mathrm{b}} \pm 0.12$ & $6.88^{\mathrm{b}} \pm 0.11$ & $6.23^{\mathrm{b}} \pm 0.15$ \\
\hline $1.5 \% \mathrm{NaCl}$ & $7.29^{\mathrm{a}} \pm 0.26$ & $10.22^{\mathrm{a}} \pm 0.24$ & $12.02^{\mathrm{a}} \pm 0.25$ & $11.51^{\mathrm{a}} \pm 0.25$ & $10.39^{\mathrm{a}} \pm 0.36$ \\
\hline$P$ - value betaine & 0.6203 & 0.6028 & $\mathbf{0 . 3 1 3 7}$ & 0.3647 & 0.1332 \\
\hline $0 \mathrm{mg}$ & $5.86 \pm 0.28$ & $7.78 \pm 0.37$ & $9.22 \pm 0.36$ & $9.32 \pm 0.30$ & $8.03 \pm 0.44$ \\
\hline $2500 \mathrm{mg}$ & $5.72 \pm 0.27$ & $7.73 \pm 0.39$ & $9.50 \pm 0.42$ & $9.07 \pm 0.41$ & $8.59 \pm 0.55$ \\
\hline Interaction & 0.9625 & 0.6503 & 0.0061 & 0.0136 & 0.0378 \\
\hline SOB0 & $4.35^{\mathrm{b}} \pm 0.15$ & $5.32^{\mathrm{b}} \pm 0.13$ & $6.95^{c} \pm 0.18$ & $7.34^{\mathrm{b}} \pm 0.13$ & $6.34^{c} \pm 0.22$ \\
\hline S0B1 & $4.23^{b} \pm 0.13$ & $5.07^{\mathrm{b}} \pm 0.12$ & $6.46^{c} \pm 0.17$ & $6.42^{\mathrm{c}} \pm 0.13$ & $6.11^{\mathrm{c}} \pm 0.19$ \\
\hline S1B0 & $7.36^{\mathrm{a}} \pm 0.38$ & $10.23^{\mathrm{a}} \pm 0.34$ & $11.49^{b} \pm 0.41$ & $11.29^{\mathrm{a}} \pm 0.30$ & $9.71^{\mathrm{b}} \pm 0.51$ \\
\hline S1B1 & $7.21^{\mathrm{a}} \pm 0.36$ & $10.21^{\mathrm{a}} \pm 0.34$ & $12.54^{\mathrm{a}} \pm 0.28$ & $11.72^{\mathrm{a}} \pm 0.41$ & $11.06^{\mathrm{a}} \pm 0.43$ \\
\hline
\end{tabular}

$\mathrm{a}, \mathrm{b}$ and $\mathrm{c}$ refer to means within the same column with different superscripts for each factor are significantly different $(\mathrm{P}<0.05)$, for interaction comparisons pairwise tests of differences (PDIFF) were used. The treatments are fresh water without betaine ( $\mathrm{S} 0 \mathrm{~B} 0)$, fresh water with betaine ( $\mathrm{S} 0 \mathrm{~B} 1)$, saline water without betaine (S1B0) and betaine with saline water (S1B1)

\section{Food consumption:}

Concentrate, roughage, and dry matter consumption ( $\mathrm{Kg} /$ day) are shown in Tables (3 to 5). The results indicated that saline water consumption decreased $(\mathrm{P}<0.01)$ the concentrate consumption compared with the fresh water group in the later three months of the experiment. Moreover, saline water consumption decreased $(\mathrm{P}<0.01)$ both the roughage consumption and dry matter consumption all over the experimental period. However, the concentrate consumption was not affected by betaine supplementation during the experimental period. While lambs supplemented with $2500 \mathrm{mg}$ betaine/ $\mathrm{kg}$ consume lower roughage $(\mathrm{P}<0.05)$ than those unsupplemented with betaine during the first month of the experiment. In contrast, betaine increased the roughage consumption during following months. The differences were significant $(\mathrm{P}<0.01)$ only during both the second and third months. Likewise, betaine increased the dry matter consumption $(\mathrm{P}<0.01)$ during second month by $3.44 \%$ compared with $0 \%$ betaine group.

The results of the four groups of interaction showed that the S0B0 group and S0B1 groups had higher $(\mathrm{P}<0.01)$ concentrate and roughage intake than the other two groups (S1B0 and S1B1).In addition, during the first month, the roughage consumption of S1B0 group was significantly $(\mathrm{P}<0.01)$ higher than the $\mathrm{S} 1 \mathrm{~B} 1$ group. However, during the second and third month, the roughage consumption of S1B1 group was $47.61 \%$ and $21.42 \%$ higher than the S1B0 group, respectively. Moreover, in the first month, both S0B0 and S0B1 groups had significantly $(\mathrm{P}<0.01)$ higher dry matter consumption than S1B1 group, but only S0B0 group had significantly $(\mathrm{P}<0.05)$ higher dry matter consumption than S1B0 group. In the following months, both S0B0 and S0B1 groups had significantly $(\mathrm{P}<0.01)$ higher dry matter consumption than S1B0 and S1B1 groups. During the second and third months, the dry matter consumption of S1B1 group was $8.33 \%$ and $7.27 \%$ higher than the S1B0 group, respectively.

Table 3. Concentrate consumption (Kg/day/head) of growing lambs as affected by saline water, betaine, and their interaction during the experimental period

\begin{tabular}{lccccc}
\hline Factors & First Month & Second Month & Third Month & Fourth Month & Fifth Month \\
\hline P- value of salinity & $\mathbf{0 . 6 5 5 7}$ & $\mathbf{0 . 6 3 4 1}$ & $<.0001$ & $<.0001$ & $\mathbf{0 . 0 0 0 3}$ \\
Fresh & $0.90 \pm 0.01$ & $0.96 \pm 0.01$ & $1.00^{\mathrm{a}} \pm 0.00$ & $1.00^{\mathrm{a}} \pm 0.00$ & $1.00^{\mathrm{a}} \pm 0.00$ \\
$1.5 \% \mathrm{NaCl}$ & $0.89 \pm 0.01$ & $0.96 \pm 0.01$ & $0.93 \mathrm{~b} \pm 0.02$ & $0.83 \mathrm{~b} \pm 0.02$ & $0.86 \mathrm{~b} \pm 0.03$ \\
P- value of betaine & $\mathbf{0 . 8 7 2 4}$ & $\mathbf{0 . 6 8 7 1}$ & $\mathbf{0 . 4 2 3 3}$ & $\mathbf{0 . 8 1 7 6}$ & $\mathbf{0 . 8 2 8 3}$ \\
$0 \mathrm{mg}$ & $0.89 \pm 0.01$ & $0.96 \pm 0.01$ & $0.96 \pm 0.01$ & $0.91 \pm 0.02$ & $0.93 \pm 0.03$ \\
$2500 \mathrm{mg}$ & $0.89 \pm 0.01$ & $0.96 \pm 0.01$ & $0.97 \pm 0.01$ & $0.92 \pm 0.02$ & $0.94 \pm 0.03$ \\
Interaction & $\mathbf{0 . 8 7 2 4}$ & $\mathbf{0 . 6 8 7 1}$ & $\mathbf{0 . 0 2 3 3}$ & $\mathbf{0 . 0 1 7 6}$ & $\mathbf{0 . 0 2 8 3}$ \\
S0B0 & $0.90 \pm 0.02$ & $0.96 \pm 0.01$ & $1.00^{\mathrm{a}} \pm 0.00$ & $1.00^{\mathrm{a}} \pm 0.00$ & $1.00^{\mathrm{a}} \pm 0.00$ \\
S0B1 & $0.90 \pm 0.02$ & $0.96 \pm 0.01$ & $1.00^{\mathrm{a}} \pm 0.00$ & $1.00^{\mathrm{a}} \pm 0.00$ & $1.00^{\mathrm{a}} \pm 0.00$ \\
S1B0 & $0.89 \pm 0.02$ & $0.96 \pm 0.01$ & $0.92 \mathrm{~b} \pm 0.02$ & $0.83 \mathrm{~b} \pm 0.03$ & $0.86 \mathrm{~b} \pm 0.05$ \\
S1B1 & $0.89 \pm 0.02$ & $0.96 \pm 0.01$ & $0.94 \mathrm{~b} \pm 0.02$ & $0.84 \mathrm{~b} \pm 0.03$ & $0.87 \mathrm{~b} \pm 0.05$ \\
\hline
\end{tabular}

$\mathrm{a}, \mathrm{b}$ and $\mathrm{c}$ refer to means within the same column with different superscripts for each factor are significantly different $(\mathrm{P}<0.05)$, for interaction comparisons pairwise tests of differences (PDIFF) were used. The treatments are fresh water without betaine $(\mathrm{S} 0 \mathrm{~B} 0)$, fresh water with betaine $(\mathrm{S} 0 \mathrm{~B} 1)$, saline water without betaine $(\mathrm{S} 1 \mathrm{~B} 0)$ and betaine with saline water (S1B1). 
Table 4. Roughage consumption (Kg/day/head) of growing lambs as affected by saline water, betaine, and their interaction during the experimental period

\begin{tabular}{|c|c|c|c|c|c|}
\hline Factors & First Month & Second Month & Third Month & Fourth Month & Fifth Month \\
\hline P-value of salinity & $<.0001$ & $<.0001$ & $<.0001$ & $<.0001$ & $<.0001$ \\
\hline Fresh & $0.28^{\mathrm{a}} \pm 0.01$ & $0.37^{\mathrm{a}} \pm 0.00$ & $0.39^{\mathrm{a}} \pm 0.00$ & $0.45^{\mathrm{a}} \pm 0.01$ & $0.50^{\mathrm{a}} \pm 0.01$ \\
\hline $1.5 \% \mathrm{NaCl}$ & $0.20^{b} \pm 0.01$ & $0.26^{\mathrm{b}} \pm 0.01$ & $0.31^{\mathrm{b}} \pm 0.01$ & $0.27^{b} \pm 0.01$ & $0.26^{b^{b}} \pm 0.02$ \\
\hline$P$ - value of betaine & 0.0138 & 0.0002 & 0.0058 & 0.2618 & 0.2773 \\
\hline $0 \mathrm{mg}$ & $0.26^{\mathrm{a}} \pm 0.01$ & $0.29^{\mathrm{b}} \pm 0.01$ & $0.34^{\mathrm{b}} \pm 0.01$ & $0.35 \pm 0.02$ & $0.37 \pm 0.03$ \\
\hline $2500 \mathrm{mg}$ & $0.23^{b} \pm 0.01$ & $0.33^{\mathrm{a}} \pm 0.01$ & $0.37^{\mathrm{a}} \pm 0.01$ & $0.37 \pm 0.01$ & $0.40 \pm 0.03$ \\
\hline Interaction & 0.0543 & $<.0001$ & 0.0018 & 0.3494 & 0.5252 \\
\hline S0B0 & $0.29^{\mathrm{a}} \pm 0.01$ & $0.38^{\mathrm{a}} \pm 0.01$ & $0.40^{\mathrm{a}} \pm 0.00$ & $0.45^{\mathrm{a}} \pm 0.01$ & $0.50{ }^{\mathrm{a}} \pm 0.01$ \\
\hline S0B1 & $0.28^{\mathrm{a}} \pm 0.01$ & $0.36^{\mathrm{a}} \pm 0.01$ & $0.39^{\mathrm{a}} \pm 0.00$ & $0.45^{\mathrm{a}} \pm 0.01$ & $0.51^{\mathrm{a}} \pm 0.02$ \\
\hline S1B0 & $0.23^{\mathrm{b}} \pm 0.01$ & $0.21^{\mathrm{c}} \pm 0.02$ & $0.28^{\mathrm{c}} \pm 0.02$ & $0.25^{\mathrm{b}} \pm 0.01$ & $0.24^{\mathrm{b}} \pm 0.03$ \\
\hline S1B1 & $0.17^{\mathrm{c}} \pm 0.01$ & $0.31^{\mathrm{b}} \pm 0.01$ & $0.34^{\mathrm{b}} \pm 0.01$ & $0.28^{\mathrm{b}} \pm 0.01$ & $0.28^{\mathrm{b}} \pm 0.03$ \\
\hline
\end{tabular}

$\mathrm{a}, \mathrm{b}$ and $\mathrm{c}$ refer to means within the same column with different superscripts for each factor are significantly different $(\mathrm{P}<0.05)$, for interaction comparisons pairwise tests of differences (PDIFF) were used. The treatments are fresh water without betaine (S0B0), fresh water with betaine (S0B1), saline water without betaine (S1B0) and betaine with saline water (S1B1).

Table 5. Dry matter consumption (Kg/day/head) of growing lambs as affected by saline water, betaine, and their interaction during the experimental period.

\begin{tabular}{|c|c|c|c|c|c|}
\hline & First Month & Second Month & Third Month & Fourth Month & Fifth Month \\
\hline P- value of salinity & 0.0002 & $<.0001$ & $<.0001$ & $<.0001$ & $<.0001$ \\
\hline Fresh & $1.09^{\mathrm{a}} \pm 0.01$ & $1.23^{\mathrm{a}} \pm 0.01$ & $1.29^{\mathrm{a}} \pm 0.00$ & $1.34^{\mathrm{a}} \pm 0.01$ & $1.38^{\mathrm{a}} \pm 0.01$ \\
\hline $1.5 \% \mathrm{NaCl}$ & $1.01^{\mathrm{b}} \pm 0.01$ & $1.12^{\mathrm{b}} \pm 0.01$ & $1.14^{\mathrm{b}} \pm 0.02$ & $1.02^{\mathrm{b}} \pm 0.02$ & $1.04^{\mathrm{b}} \pm 0.04$ \\
\hline P- value of betaine & 0.215 & $\mathbf{0 . 0 0 3 7}$ & 0.0667 & 0.4718 & 0.4809 \\
\hline $0 \mathrm{mg}$ & $1.06 \pm 0.02$ & $1.16^{\mathrm{b}} \pm 0.01$ & $1.20 \pm 0.02$ & $1.17 \pm 0.03$ & $1.19 \pm 0.05$ \\
\hline $2500 \mathrm{mg}$ & $1.03 \pm 0.02$ & $1.20^{\mathrm{a}} \pm 0.01$ & $1.23 \pm 0.02$ & $1.19 \pm 0.03$ & $1.23 \pm 0.04$ \\
\hline Interaction & 0.3488 & $<.0001$ & 0.0454 & 0.5293 & 0.6315 \\
\hline S0B0 & $1.09^{\mathrm{a}} \pm 0.02$ & $1.24^{\mathrm{a}} \pm 0.01$ & 1. $29^{\mathrm{a}} \pm 0.00$ & $1.33^{\mathrm{a}} \pm 0.01$ & $1.38^{\mathrm{a}} \pm 0.01$ \\
\hline S0B1 & $1.08^{a b} \pm 0.02$ & $1.22^{\mathrm{a}} \pm 0.01$ & $1.28^{\mathrm{a}} \pm 0.00$ & $1.34^{\mathrm{a}} \pm 0.01$ & $1.39^{\mathrm{a}} \pm 0.02$ \\
\hline S1B0 & $1.03^{b c} \pm 0.02$ & $1.08^{\mathrm{c}} \pm 0.01$ & $1.10^{\mathrm{c}} \pm 0.03$ & $1.00^{\mathrm{b}} \pm 0.03$ & $1.01^{\mathrm{b}} \pm 0.06$ \\
\hline S1B1 & $0.98^{\mathrm{c}} \pm 0.02$ & $1.17^{\mathrm{b}} \pm 0.01$ & $1.18^{\mathrm{b}} \pm 0.03$ & $1.04^{\mathrm{b}} \pm 0.04$ & $1.06^{\mathrm{b}} \pm 0.05$ \\
\hline
\end{tabular}

$\mathrm{a}, \mathrm{b}$ and $\mathrm{c}$ refer to means within the same column with different superscripts for each factor are significantly different $(\mathrm{P}<0.05)$, for interaction comparisons pairwise tests of differences (PDIFF) were used. The treatments are fresh water without betaine $(\mathrm{S} 0 \mathrm{~B} 0)$, fresh water with betaine $(\mathrm{S} 0 \mathrm{~B} 1)$, saline water without betaine $(\mathrm{S} 1 \mathrm{~B} 0)$ and betaine with saline water (S1B1).

Body weight and daily gain:

The body weights and average daily gain of lambs are shown in Tables (6) and Figure (1). Drinking saline water significantly $(\mathrm{P}<0.01)$ decreased both final body weight and average daily gain by $22.64 \%$ and $64.03 \%$, respectively compared with the fresh water group. On the other hand, betaine supplementation increased the final body weight by $12.93 \% \quad(\mathrm{P}<0.05)$.In addition, betaine supplementation increased the average daily gain of lambs by $26.36 \%$.

Table 6. Body weight (Kg) and daily gain of growing lambs as affected by saline water, betaine, and their interaction during the experimental period.

\begin{tabular}{|c|c|c|c|}
\hline Factors & Initial weight & Final body weight (Kg) & Average daily gain \\
\hline P- value of salinity & 0.6269 & 0.0009 & 0.0004 \\
\hline Fresh & $31.66 \pm 1.28$ & $44.83^{\mathrm{a}} \pm 2.20$ & $102.73^{a} \pm 10.46$ \\
\hline $1.5 \% \mathrm{NaCl}$ & $31.51 \pm 0.96$ & $34.68^{\mathrm{b}} \pm 1.07$ & $36.95^{\mathrm{b}} \pm 10.85$ \\
\hline$P$ - value of betaine & 0.6549 & 0.0399 & 0.1765 \\
\hline 0 mg & $31.54 \pm 1.22$ & $37.34^{b} \pm 1.82$ & $60.89 \pm 14.96$ \\
\hline $2500 \mathrm{mg}$ & $31.62 \pm 0.96$ & $42.17^{\mathrm{a}} \pm 3.26$ & $76.12 \pm 15.70$ \\
\hline Interaction & 0.509545 & 0.071078 & 0.8891 \\
\hline S0B0 & $31.44 \pm 2.15$ & $41.25^{\mathrm{b}} \pm 0.18$ & $94.34^{\mathrm{a}} \pm 12.24$ \\
\hline S0B1 & $31.93 \pm 1.43$ & $48.40^{\mathrm{a}} \pm 3.37$ & $113.23^{\mathrm{a}} \pm 18.46$ \\
\hline S1B0 & $31.64 \pm 1.45$ & $33.43^{c} \pm 1.10$ & $27.45^{\mathrm{b}} \pm 17.26$ \\
\hline S1B1 & $31.38 \pm 1.43$ & $35.93^{b c} \pm 1.71$ & $46.44^{b} \pm 13.68$ \\
\hline
\end{tabular}

$\mathrm{a}, \mathrm{b}$ and $\mathrm{c}$ refer to means within the same column with different superscripts for each factor are significantly different $(\mathrm{P}<0.05)$, for interaction comparisons pairwise tests of differences (PDIFF) were used. The treatments are fresh water without betaine $(\mathrm{S} 0 \mathrm{~B} 0)$, fresh water with betaine $(\mathrm{S} 0 \mathrm{~B} 1)$, saline water without betaine $(\mathrm{S} 1 \mathrm{~B} 0)$ and betaine with saline water (S1B1). 


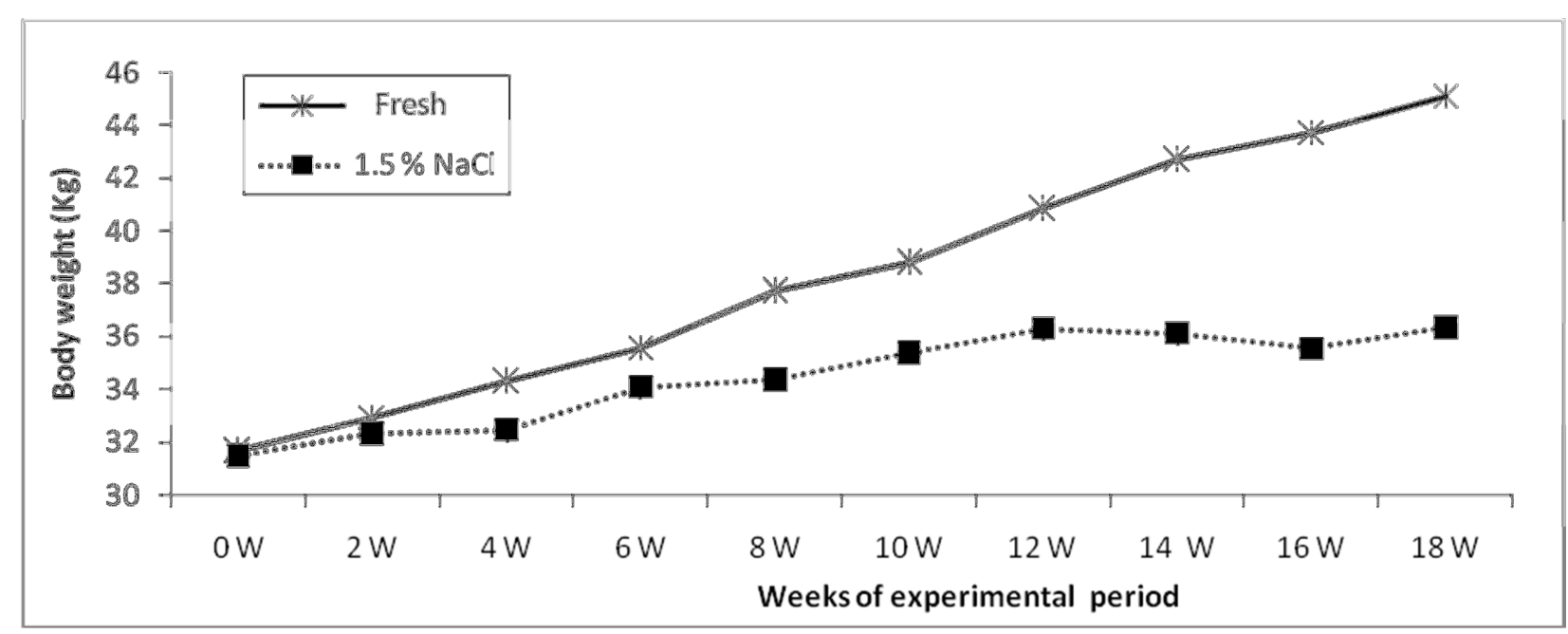

Figure 1A

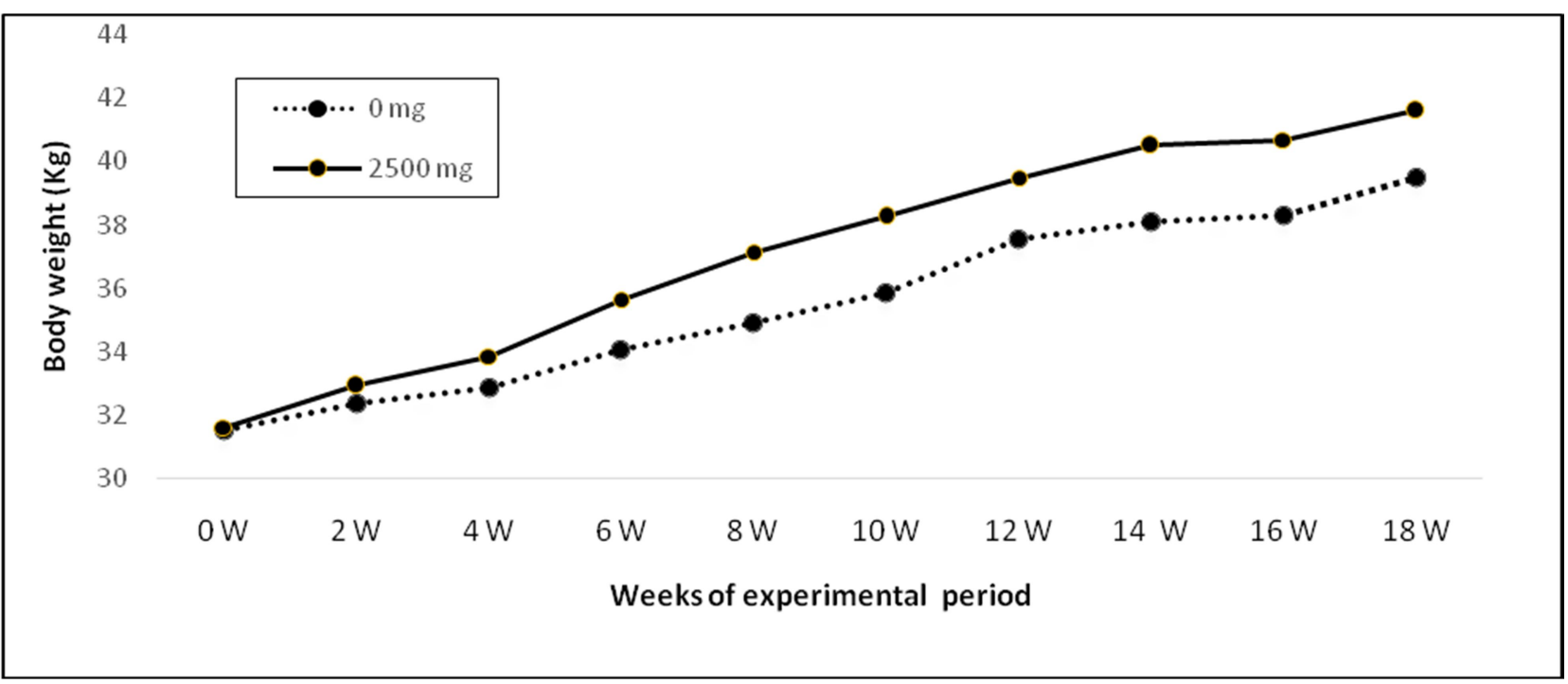

Figure 1B

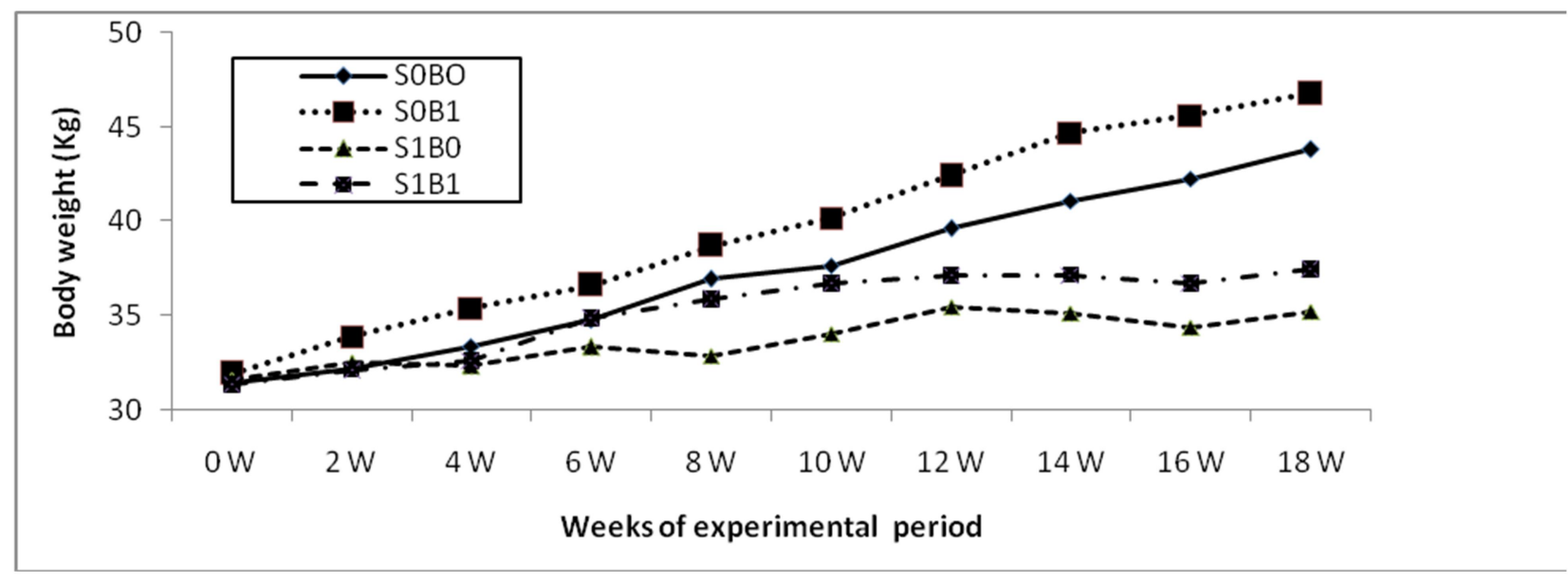

Figure 1C

Figure 1. Body weight (Kg) of growing lambs as affected by saline water (A), betaine (B), and their interaction $(C)$ during the experimental period. The treatments are fresh water without betaine (S0B0), fresh water with betaine (S0B1), saline water without betaine (S1B0) and betaine with saline water (S1B1) 
The interaction showed that the final body weight of S0B1 group was significantly higher than the other groups. In addition, the final body weight of S1B0 group was significantly $(\mathrm{P}<0.05)$ lower than the S0B0 group. However, no significant differences were observed between S0B0 and S1B1 groups. In addition, both S0B0 and S0B1 groups had higher $(\mathrm{P}<0.01)$ average daily gain than both $\mathrm{S} 1 \mathrm{~B} 0$ and S1B1 groups. The average daily gain of S1B1 group was slightly higher than the S1B0 group. Similarly, the average daily gain of the S0B1 group was slightly higher than S0B0 group.

\section{Respiration rate and rectal temperature:}

The results of the respiration rate and rectal temperature are shown in Table (7). Saline water consumption and betaine supplementation did not affect the respiration rate of lambs. On the other hand, betaine supplementation significantly $(\mathrm{P}<0.01)$ increased the rectal temperature only in the morning, but saline water consumption had no effect on rectal temperature. The interaction showed that at morning the $\mathrm{S} 0 \mathrm{~B} 1$ group had higher $(\mathrm{P}<0.05)$ respiration rate than the S1B0 group. However, the other two groups had intermediate values. At morning, the rectal temperature of S0B1 group was higher $(\mathrm{P}<0.01)$ than the S0B0 group and the S1B0 group. In addition,S1B1 group had intermediate value. At evening, the rectal temperature of the S1B1 group was lower $(\mathrm{P}<0.05)$ than the $\mathrm{S} 0 \mathrm{~B} 1$ group $(\mathrm{P}<0.01)$ and S1B0 group. while, the S0B0 group had intermediate value.

Table 7. Respiration rate and rectal temperature of growing lambs as affected by saline water, betaine, and their interaction during the experimental period

\begin{tabular}{|c|c|c|c|c|}
\hline \multirow{2}{*}{ Factors } & \multicolumn{2}{|c|}{ Respiration rate } & \multicolumn{2}{|c|}{ Rectal temperature } \\
\hline & AM & PM & $\mathrm{AM}$ & PM \\
\hline P- value of salinity & 0.2479 & 0.2279 & 0.2905 & 0.1101 \\
\hline Fresh & $49.11 \pm 1.32$ & $62.94 \pm 1.97$ & $39.12 \pm 0.07$ & $39.57 \pm 0.05$ \\
\hline $1.5 \% \mathrm{NaCl}$ & $46.24 \pm 2.11$ & $59.03 \pm 2.53$ & $39.02 \pm 0.07$ & $39.46 \pm 0.05$ \\
\hline P- value of betaine & 0.0766 & 0.7110 & 0.0002 & 0.5560 \\
\hline $0 \mathrm{mg}$ & $45.47 \pm 1.83$ & $60.39 \pm 2.22$ & $38.90^{\mathrm{b}} \pm 0.08$ & $39.54 \pm 0.06$ \\
\hline $2500 \mathrm{mg}$ & $49.89 \pm 1.65$ & $61.59 \pm 2.34$ & $39.25^{\mathrm{a}} \pm 0.05$ & $39.50 \pm 0.05$ \\
\hline Interaction & 0.1625 & 0.0135 & 0.9586 & $\mathbf{0 . 8 8 7 7}$ \\
\hline S0B0 & $46.97^{\mathrm{ab}} \pm 1.97$ & $62.11 \pm 2.64$ & $38.88^{\mathrm{b}} \pm 0.12$ & $39.51^{\mathrm{ab}} \pm 0.07$ \\
\hline S0B1 & $51.26^{\mathrm{a}} \pm 1.70$ & $63.77 \pm 2.97$ & $39.36^{\mathrm{a}} \pm 0.06$ & $39.64^{\mathrm{a}} \pm 0.06$ \\
\hline S1B0 & $43.97^{b} \pm 3.10$ & $58.66 \pm 3.59$ & $38.91^{\mathrm{b}} \pm 0.11$ & $39.57^{\mathrm{a}} \pm 0.09$ \\
\hline S1B1 & $48.51^{\mathrm{ab}} \pm 2.84$ & $59.40 \pm 3.62$ & $39.13^{\mathrm{ab}} \pm 0.07$ & $39.35^{\mathrm{b}} \pm 0.06$ \\
\hline
\end{tabular}

$\mathrm{a}$ and $\mathrm{b}$ refer to means within the same column with different superscripts for each factor are significantly different $(\mathrm{P}<0.05)$, for interaction comparisons pairwise tests of differences (PDIFF) were used. The treatments are fresh water without betaine (S0B0), fresh water with betaine (S0B1), saline water without betaine (S1B0) and betaine with saline water (S1B1).

\section{Plasma constituents:}

Plasma parameters are shown in Table (8). Offering saline water didn't affect the plasma total protein, globulin, cholesterol, triglycerides and glucose. However, saline water significantly $(\mathrm{P}<0.01)$ increased the plasma albumin concentration. Moreover, betaine supplementation did not affect the plasma total protein, globulin and glucose. However, betaine significantly $(\mathrm{P}<0.01)$ increased the plasma albumin concentration. On the other hand, betaine significantly $(\mathrm{P}<0.05) \quad$ decreased the plasma cholesterol and triglycerides concentrations compared with $0 \mathrm{mg}$ betaine group.

The differences among the four groups of interaction showed that, the plasma albumin concentration of S1B1 group was significantly $(\mathrm{P}<0.01)$ higher than the other three groups $(\mathrm{S} 0 \mathrm{~B} 0$,
S0B1, and S1B0). The plasma globulin concentration of S1B1 group was significantly $(\mathrm{P}<0.05)$ lower than both S0B1 and S1B0 groups, the S0B0 had intermediate value. Moreover, the plasma cholesterol concentrations of the S1B1 group were significantly $(\mathrm{P}<0.01)$ lower than both $\mathrm{S} 0 \mathrm{~B} 1$ and $\mathrm{S} 1 \mathrm{~B} 0$ groups. In addition, the S0B0 group had significantly $(\mathrm{P}<0.05)$ lower cholesterol concentrations than S1B0 group. In addition, the plasma triglycerides concentrations of the S1B1 group were significantly $(\mathrm{P}<0.05)$ lower than the S0B0 group, while the other two groups had intermediate values. In addition, the plasma glucose of S0B1 group were significantly higher than S0B0 group $(\mathrm{P}<0.01)$ and $\mathrm{S} 1 \mathrm{~B} 1(\mathrm{P}<0.05)$, the $\mathrm{S} 1 \mathrm{~B} 0$ group had intermediate value. 
Egyptian J. Anim. Prod. (2019)

Table 8. Plasma parameters of growing lambs as affected by saline water, betaine, and their interaction.

\begin{tabular}{|c|c|c|c|c|c|c|}
\hline Factors & $\begin{array}{c}\text { Total } \\
\text { protein }\end{array}$ & Albumin & Globulin & Cholesterol & Triglycerides & Glucose \\
\hline P- value of salinity & 0.2269 & 0.0014 & 0.1598 & 0.4747 & 0.4832 & 0.5274 \\
\hline Fresh & $6.03 \pm 0.05$ & $3.84^{\mathrm{b}} \pm 0.04$ & $2.18 \pm 0.06$ & $205.21 \pm 2.56$ & $178.74 \pm 1.22$ & $79.18 \pm 1.30$ \\
\hline $1.5 \% \mathrm{NaCl}$ & $6.08 \pm 0.05$ & $4.01^{\mathrm{a}} \pm 0.05$ & $2.07 \pm 0.06$ & $202.68 \pm 2.65$ & $174.82 \pm 1.79$ & $78.64 \pm 1.27$ \\
\hline$P$ - value of betaine & 0.1647 & 0.0036 & 0.2886 & 0.0475 & 0.0235 & 0.0515 \\
\hline $0 \mathrm{mg}$ & $6.02 \pm 0.05$ & $3.85^{\mathrm{b}} \pm 0.04$ & $2.17 \pm 0.07$ & $206.51 \stackrel{\mathrm{a}}{\mathrm{a}} \pm 2.62$ & $182.67^{\mathrm{a}} \pm 2.10$ & $78.10 \pm 1.26$ \\
\hline $2500 \mathrm{mg}$ & $6.10 \pm 0.04$ & $4.01 \stackrel{\mathrm{a}}{ \pm} \pm 0.04$ & $2.08 \pm 0.05$ & $201.62^{\mathrm{b}} \pm 2.55$ & $171.38^{\mathrm{b}} \pm 1.92$ & $79.70 \pm 1.28$ \\
\hline Interaction & 0.7252 & 0.0224 & 0.0593 & $<.0001$ & 0.7995 & 0.0316 \\
\hline S0B0 & $5.98 \pm 0.07$ & $3.84^{\mathrm{b}} \pm 0.06$ & $2.14^{\mathrm{ab}} \pm 0.09$ & $202.26^{\mathrm{bc}} \pm 3.00$ & $182.97^{\mathrm{a}} \pm 2.76$ & $77.18^{\mathrm{b}} \pm 1.79$ \\
\hline S0B1 & $6.07 \pm 0.06$ & $3.87^{\mathrm{b}} \pm 0.07$ & $2.20^{\mathrm{a}} \pm 0.07$ & $207.59 \stackrel{\mathrm{ab}}{{ }^{2}} \pm 4.01$ & $173.99^{\mathrm{ab}} \pm 3.34$ & $80.99^{\mathrm{a}} \pm 1.84$ \\
\hline S1B0 & $6.06 \pm 0.08$ & $3.89^{\mathrm{b}} \pm 0.07$ & $2.18^{\mathrm{a}} \pm 0.09$ & $210.59^{\mathrm{a}} \pm 4.13$ & $181.01^{\mathrm{ab}} \pm 2.99$ & $78.60^{\mathrm{ab}} \pm 1.85$ \\
\hline S1B1 & $6.12 \pm 0.06$ & $4.16^{\mathrm{a}} \pm 0.05$ & $1.96^{\mathrm{b}} \pm 0.07$ & $195.95^{c^{c}} \pm 2.84$ & $169.80^{\mathrm{b}} \pm 1.84$ & $78.40^{\mathrm{b}} \pm 1.77$ \\
\hline
\end{tabular}

$\mathrm{a}, \mathrm{b}$ and $\mathrm{c}$ means within the same column with different superscripts for each factor are significantly different $(\mathrm{P}<0.05)$ of all pairwise tests of treatment differences for interaction (PDIFF). The treatments are fresh water without betaine (S0B0), fresh water with betaine (S0B1), saline water without betaine (S1B0) and saline water with betaine (S1B1).

\section{DISCUSSION}

The detrimental effects of consuming saline water had been showed by The Agricultural Research Council (1980). Those detrimental effects are the low appetite, poor performance and the damaged animal's kidneys. In the present study, lambs consuming saline water had lower performance (low feed consumption, body weight and daily gain) and dramatically increased water consumption. Our results are similar to those found by Yousfi et al. (2016) and Yousfi and Salem (2017).

The increased water consumption associated with offering saline water may be due to helping the kidney to remove excess salts (Kii and Dryden, 2005). Potter (1961) concluded that removing excess salts happens through increasing of glomerular filtration rate. Another reason was given by Goldstein and Skadhauge (2000). They suggested that the saline water decreases the secretion of renin and increases angiotensin II which leads to increase of water consumption.

In the current study consuming saline water decreased feed intake. This result was analogous to those of Yousfi and Salem (2017). The low feed intake associated with consuming saline water could be explained by the negative effect of saline water on ruminal fluids osmolality. When animals consume saline water electrolytes concentrations such as sodium and chlorides will increase in the rumen. Subsequently, ruminal osmotic will increase (Phillip et al., 1981). High rumen osmotic pressure causes gastric distension which in turn decreases feed intake (Gregory et al., 1987).

In addition, consuming saline water significantly $(\mathrm{P}<0.01)$ decreased the final body weight and the average daily gain. These results are comparable to the study of Mdletshe et al. (2017) who found that goats average daily gain declined $(\mathrm{P}<0.05)$ with consuming saline water. The lower average daily gain of saline water consuming animals could be explained by lower feed intake and higher water consumption (Alves et al., 2017). In addition, drinking saline water increases urination to remove excess salts, which in turn make the animals face digestive and metabolic disorders, which in turn could decrease the body weight of animals (Masters et al., 2007).

On the other hand, the current study showed that betaine did not affect water consumption when lambs drinking fresh or saline water. In contrast, our results showed improvement of roughage and dry matter intake in the S1B1 group compared with the S1B0 group which was mainly due to betaine supplementation. The effect of betaine on feed consumption may be due to the roles of betaine as an osmolyte. As an osmolyte, betaine prevents enzymes and cell membranes from inactivation by inorganic ions (Petronini et al., 1992).

Moreover, betaine supplementation increased the final body weight by $12.93 \%$ and the average daily gain by $26.36 \%$. Similar results were observed in finishing pigs by Huang et al. (2009). The high body weight and average daily gain of dietary betaine supplementation might be due to the increase of feed intake of betaine group and the improvement of nutrients digestibility (Eklund et al., 2005). Moreover, Esteve-Garcia and Mack (2000) showed that betaine could increase the body weight by increasing the water retention of the muscle's tissues.

Moreover, betaine could increase body weight and daily gain during saline water consumption via increasing nutrients absorption. Betaine reduces the energy required for ion pumping and osmoregulation in intestine. The saved energy increases intestinal cell proliferation which leads to more gut surface for nutrient absorption (Siljander-Rasi et al. 2003).

Saline water did not affect the respiration rate and rectal temperature of lambs. Similarly, Mdletshe et al. (2017) found that saline water did not affect the respiration rate in goats. In addition, Badawy (1999) found that offering saline water $(1.5 \%$ TDS) did not affect the rectal temperature in Saidi rams. 
In addition, dietary betaine supplementation did not affect the respiration rate. On the other hand, betaine significantly $(\mathrm{P}<0.01)$ increased the rectal temperature only in the morning. Similarly, Hall (2014) showed that betaine $(57 \mathrm{mg} / \mathrm{kg}$ of body weight) increased $(\mathrm{P}<0.01)$ the rectal temperature in Holstein cows subjected to thermal stress. The author explained the higher rectal temperature associated with betaine supplementation that betaine increases rumen activity. As a result, more fermentation heat is produced. Consequently, the core body temperature increases (Conrad, 1985).

Biochemically, saline water significantly $(\mathrm{P}<0.01) \quad$ increased the plasma albumin concentration. Similarly, Badawy (1999) showed that offering saline water (1.5\% TDS) significantly $(\mathrm{P}<0.01)$ increased the serum albumin concentrations in Saidi sheep. The increase of plasma albumin might be related to high level of Sodium ions. $\mathrm{Na}$ ions have an important role in the absorption of amino acids from the gut. Subsequently, the utilization of high level of amino acids increases and enhances the formation of plasma proteins (Ganong, 2003). In addition, betaine significantly $(\mathrm{P}<0.01)$ increased the plasma albumin concentration. The higher plasma albumin concentrations might had resulted in the higher feed intake of lambs fed dietary betaine.

However, betaine significantly $(\mathrm{P}<0.05)$ decreased the plasma cholesterol and triglycerides concentrations. Similarly, Fernandez et al. (2009) showed that betaine at $4 \mathrm{~g} / \mathrm{kg}$ of diet significantly $(\mathrm{P}<0.05)$ decreased serum concentrations of triglycerides in dairy goats. In addition, blood cholesterol concentrations were decreased by dietary betaine supplementation in pigs (Yang et al., 2009).

\section{CONCLUSION}

The current study showed two important findings, first betaine may reduce the deleterious effects of drinking saline or high TDS water by growing lambs, second, betaine can be use as supplement to improve growing lambs' performance and growth. Consequently, the present study strongly recommends to used betaine supplement for growing lambs specially for those are rearing in areas depending on groundwater with high $\mathrm{NaCl}$ content.

\section{REFERENCES}

Agricultural Research Council, 1980. Common wealth Agricultural Bureaux. The Nutrient requirements of ruminant livestock: technical review. CAB Intl.

Alves, J., G. Araújo, S. Neto, T. Voltolini, R. Santos, P. Rosa, L. Guan, T. McAllister and A. Neves, 2017. Effect of increasing concentrations of total dissolved salts in drinking water on digestion, performance and water balance in heifers. J. Agri. Sci., 155, 847856.
AOAC., 2012. Official methods of analysis.19th ed. Association of Official Analytical Chemists. Washington, DC.

Badawy, H. S. M., 1999. Digestive Function and Heat Regulation in Saidi Sheep.M.Sc., Assiut University, Egypt.

Conrad, J. H., 1985. Feeding of farm animals in hot and cold environments.Pages 205-226 in Stress Physiology in Livestock.Vol. 1. M. K. Yousef, ed. CRC Press, Boca Raton, FL

Craig, S. A., 2004. Betaine in human nutrition. The American journal of clinical nutrition 80 : 539549.

Curran, G., and S. Robson, 2007. Water for livestock: interpreting water quality tests. Prime facts 533: 1-5.

Duncan, D. B., 1955. Multiple Range and Multiple F Tests. Biometrics, 11(1): 1-42.

Eklund, M., E. Bauer, J. Wamatu, and R. Mosenthin, 2005.Potential nutritional and physiological functions of betaine in livestock. Nutrition research reviews 18: 31-48.

Esteve-Garcia, E., and S. Mack, 2000. The effect of DL-methionine and betaine on growth performance and carcass characteristics in broilers. Animal Feed Science and Technology 87: 85-93.

Feng, J., X. LIU, Y. Z. Wang, and Z. R. Xu, 2006.Effects of betaine on performance, carcass characteristics and hepatic betaine homocysteine methyl transferase activity in finishing barrows. Asian Australasian Journal of Animal Sciences 19: 402-405.

Fernandez, C. J., C. M. Mata-anguiano, O. PiquerQuerol, and F. Bacha-Baz. 2009. Influence of betaine on goat milk yield and blood metabolites. Tropical and Subtropical Agroecosystems 11: 209-213.

Ganong, W. 2003.Energy balance, metabolism and nutrition. In: Review of Medical Physiology. Lange Medical Publications. Drawerl, Los/Altos, California.

Goldstein, D., and E. Skadhauge, 2000.Renal and extrarenal regulation of body fluid composition. In, Whittow GC (Ed): Sturkie's Avian Physiology. 5th edn., Academic Press, San Diego, USA.PP: 223-226.

Gregory, P., M. McFadyen, and D. Rayner, 1987. The influence of gastrointestinal infusions of glucose on regulation of food intake in pigs. Experimental Physiology 72: 525-535.

Hall, L. W., 2014. The Evaluation of Dietary Betaine, Pre and Probiotics, Transitional Substrates, and B-Mercapto acetate on Physiological, Metabolic, Hormonal and Production Responses in Lactating Holstein Cows Subjected to Thermal Stress. PhD Thesis, Arizona, USA.

Huang, Q. C., X. Y. Han, Z. Xu, X. Y. Yang, T. Chen, and X. T. Zheng, 2009. Betaine suppresses carnitinepalmitoyl transferase I in 
skeletal muscle but not in liver of finishing pigs. Livestock Science 126: 130-135.

Kellems, R. O., and D. C. Church, 2002. Livestock feeds and feeding. Prentice Hall Upper Saddle River, NJ

Kidd, M., P. Ferket, and J. Garlich, 1997.Nutritional and osmoregulatory functions of betaine. World's Poultry Science Journal 53: 125-139.

Kii, W. Y., and G. M. Dryden, 2005. Effect of drinking saline water on food and water intake, food digestibility, and nitrogen and mineral balances of rusa deer stags (Cervustimo rensisrussa). Animal Science 81: 99-105.

Masters, D. G., S. E. Benes, and H. C. Norman, 2007.Biosaline agriculture for forage and livestock production. Agriculture, Ecosystems and Environment 119: 234-248.

Mdletshe, Z., M. Chimonyo, M. Marufu, and I. Nsahlai, 2017. Effects of saline water consumption on physiological responses in Nguni goats. Small Ruminant Research 153: 209-211.

NRC., 2007. Nutrient requirements of small ruminants: sheep, goats, cervids, and new world camelids. National Research Council, Washington, DC.

Petronini, P. G., E. De Angelis, P. Borghetti, A. Borghetti, and K. P. Wheeler, 1992. Modulation by betaine of cellular responses to osmotic stress. Biochemical Journal 282: 6973.

Phillip, L., J. Buchanan-Smith, and W. Grovum, 1981. Food intake and ruminal osmolality in sheep: differentiation of the effect of osmolality from that of the products of maize silage fermentation. The Journal of Agricultural Science 96: 439-445.

Potter, B. J., 1961. The renal response of sheep to prolonged ingestion of sodium chloride. Crop Pasture Science 12: 440-445.

SAS, institute, 2013.SAS/SAT User's Guide. Statistics Analysis Institute, Cary, NC,USA.

Siljander-Rasi, H., S. Peuranen, K. Tiihonen, E. Virtanen, H. Kettunen, T. Alaviuhkola, and P. Simmins. 2003. Effect of equi-molar dietary betaine and choline addition on performance, carcass quality and physiological parameters of pigs. Animal Science 76: 55-62.

Virtanen, E., 1995. Piecing together the betaine puzzle. Feed Mix 3: 12-17.

Yancey, P. H., M. E. Clark, S. C. Hand, R. D. Bowlus, and G. N. Somero. 1982. Living with water stress: evolution of osmolyte systems. Science 217: 1214-1222.

Yang, H. S., J. I. Lee, S. T. Joo, and G. B. Park, 2009. Effects of dietary glycine betaine on growth and pork quality of finishing pigs. Asian-Australasian Journal of Animal Sciences 22: 706-711.

Yousfi, I., and H. B. Salem, 2017.Effect of increasing levels of sodium chloride in drinking water on intake, digestion and blood metabolites in Barbarine sheep. Annales de l'INRAT 90: 202.

Yousfi, I., H. B. Salem, D. Aouadi, and S. Abidi, 2016.Effect of sodium chloride, sodium sulfate or sodium nitrite in drinking water on intake, digestion, growth rate, carcass traits and meat quality of Barbarine lamb. Small Ruminant Research 143: 43-52.

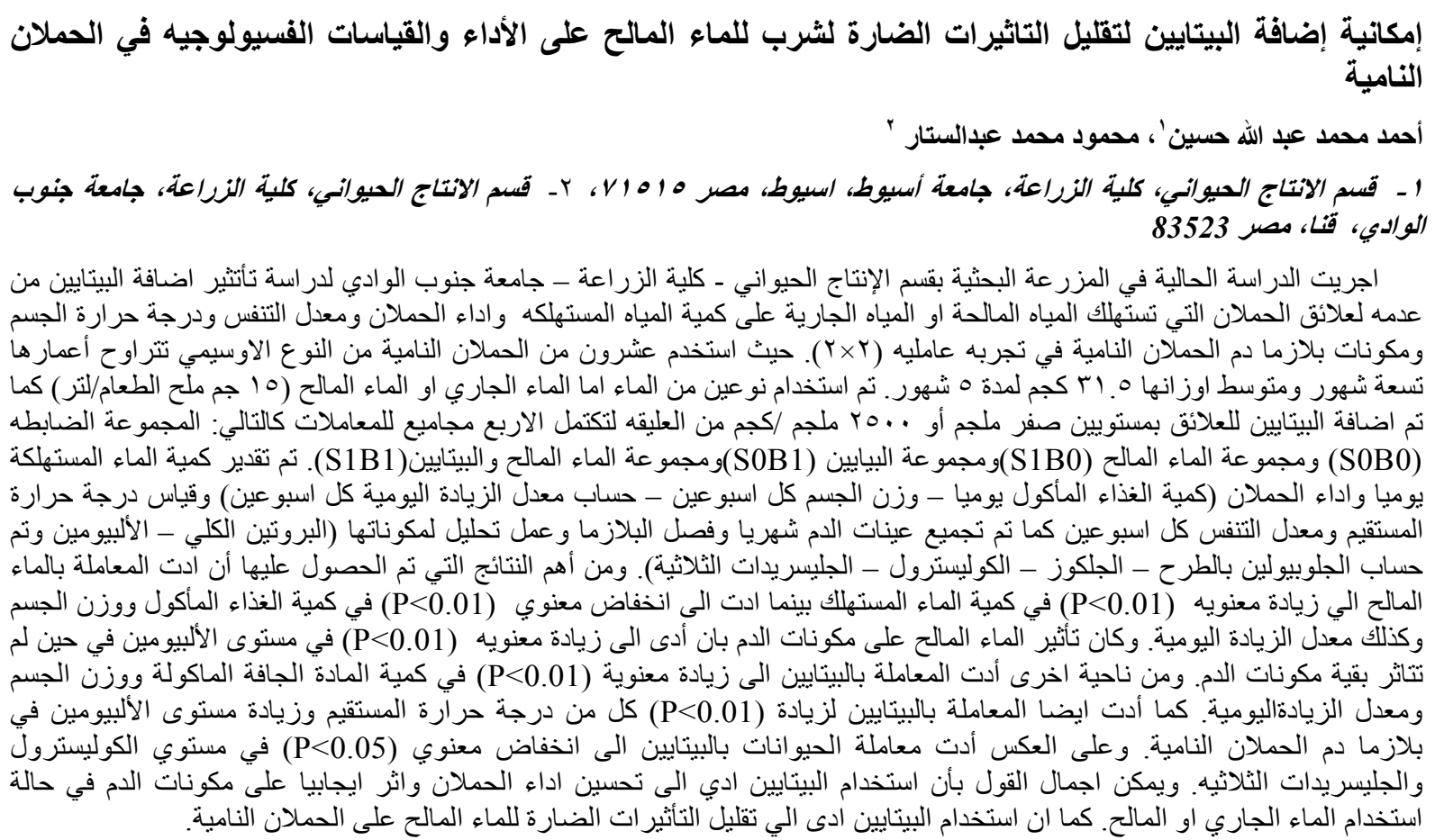

